\title{
Metazoan parasite species in cultured mussel Mytilus galloprovincialis in the Thermaikos Gulf (North Aegean Sea, Greece)
}

\author{
Abdalnasser Rayyan ${ }^{1}$, George Photis ${ }^{2}$, Chariton C. Chintiroglou ${ }^{1, *}$ \\ ${ }^{1}$ Department of Zoology, School of Biology, Box 134, Aristotle University of Thessaloniki, \\ 54006 Thessaloniki, Greece \\ ${ }^{2}$ Laboratory of Ichthyology and Fish Pathology, Veterinary Faculty, Aristotle University of Thessaloniki, \\ 54006 Thessaloniki, Greece
}

\begin{abstract}
This is the first study on parasites of cultured Mytilus galloprovincialis L. in Greek waters, and is based on samples collected every 2 to 3 mo between September 2000 and November 2001 at 3 stations in the Thermaikos Gulf. Each sample comprised 40 mussels. We found 4 metazoan parasite species: hydroid Eugymnanthea inquilina, gill turbellarian Urastoma cyprinae, trematode Proctoces maculatus and gut copepod Mytilicola intestinalis. Of 840 mussels examined, 406 (48.3\%) mussels were harbouring hydroids of E. inquilina, 278 (33.1\%) were infested with $U$. cyprinae, 94 $(11.2 \%)$ were infested with $M$. intestinalis, and only $7(0.8 \%)$ were infested with $P$. maculatus. The prevalence and intensity of these parasites were related to temperature and pollution. Mussels infested with these parasites had significantly lower condition indices than non-infested mussels; larger mussels were more often infested than smaller ones.
\end{abstract}

KEY WORDS: Mytilus galloprovincialis $\cdot$ Parasites $\cdot$ Metazoa $\cdot$ Condition index

\section{INTRODUCTION}

Bivalve culture in Greek waters is almost entirely limited to the culture of the mussel Mytilus galloprovincialis. In 1996, production reached $37000 \mathrm{t}$ (Le Breton \& Chintiroglou 1998). The farming of M. galloprovincialis in the Thermaikos Gulf is a very important commercial industry (Chintiroglou et al. 2002). Mussel culture markedly affects the ecosystem of the Thermaikos Gulf, since the high density of mussels can aid the spread of epizootic diseases. The present study was conducted to determine: (1) the species of metazoan parasites associated with farmed M. galloprovincialis in the Thermaikos Gulf; (2) the prevalence, intensity and monthly distribution of such parasites; (3) their effect on mussel condition and (4) evaluate the effects of various environmental parameters and of mussel size on parasite occurrence. Ours is the first study of metazopan parasites on M. galloprovincialis in Greek waters.

\section{MATERIALS AND METHODS}

Sampling was carried out between September 2000 and November 2001. Samples of Mytilus galloprovincialis L. were collected every 2 or 3 mo at 3 stations from longline mussel culture sites in the Thermaikos Gulf, along the boundaries of Thessaloniki Bay (Fig. 1). Sampling stations differed in terms of distance from main pollution sources in the area as well as in terms of abiotic parameters. Thus, Stn 2 was close to industrial pollution sources (Nikolaides \& Moustaka 1990), whereas Stns 1 and 3 were influenced by the currents dominating the outer part of the Thermaikos Gulf (Krestenitis et al. 1997). Anticyclonic currents in the area can alter the water circulation from one season, or year, to another (Balopoulos \& Friligos 1993).

A total of 840 mussels were collected during the study period. Each sample consisted of 20 mussels taken from the top (1 $\mathrm{m}$ depth) and 20 from the bottom ( $3 \mathrm{~m}$ depth) 


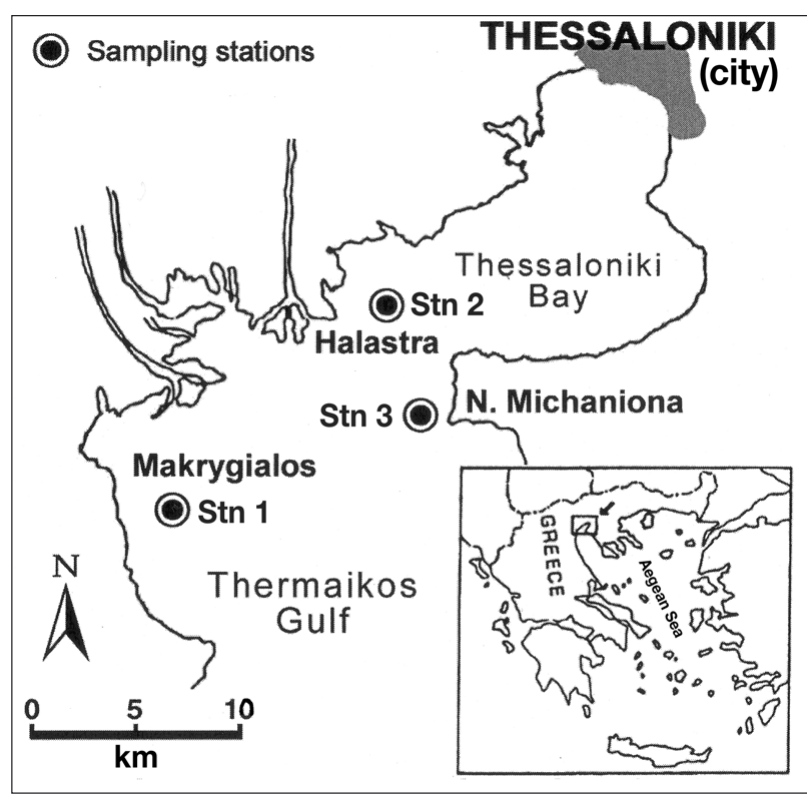

Fig. 1. Locations of the 3 sampling stations in the Thermaikos Gulf (North Aegean Sea)

of the hanging ropes ( $4 \mathrm{~m}$ in length). All mussels above $50 \mathrm{~mm}$ in shell length (commercial size) were stored without water in an icebox (ca. $4^{\circ} \mathrm{C}$ ) for a maximum of $4 \mathrm{~d}$. The water temperature was measured at each sampling location. In the laboratory, mussels were cleaned of mud and biofouling organisms and shell length was measured to the nearest $\mathrm{mm}$, and total weight (TW), wet meat weight (MW) and shell weight (SW), to the nearest gram. The mussels were then opened and intervalve water, gills, mantle and visceral mass were examined for parasites. The condition index (CI) was calculated using the formula (Aguirre 1979):

$$
\mathrm{CI}=[\mathrm{MW} /(\mathrm{TW}-\mathrm{SW})] \times 100
$$

Abundance of the hydroid Eugymnanthea inquilina (Palombi, 1935) in the mussels was classified as Class I: (1 to 50 polyps), Class II: (51 to 100 polyps) or Class III (>100 polyps); specimens of the other parasite species were counted individually. Mussels were separated into 4 size classes: 51 to $60 \mathrm{~mm}, 61$ to $70 \mathrm{~mm}, 71$ to $80 \mathrm{~mm}$ and 81 to $94 \mathrm{~mm}$.

A 1-way analysis of variance (ANOVA) was used to compare the CI of infested and non-infested mussels. Fisher's least-significance difference (LSD) test was used to analyse the effect each parasite had on the CI of mussels, as well as to identify the effect of any possible combination of parasites on the mussels (herein designated 'level of parasitism'). The relation of parasite infestation to station, mussel size and the position of mussel on the rope (top or bottom) was evaluated by a $\chi^{2}$ test. Monthly fluctuations of parasite infestation at each station were expressed as a coefficient of variation ( $\mathrm{Cv}$, i.e. ratio between standard deviation and arithmetic mean of the monthly percent infestation of a parasite at each station).

\section{RESULTS}

We found 4 metazoan parasite species associated with Mytilus galloprovincialis: Eugymnanthea inquilina (Palombi, 1935), a bivalve-inhabiting hydroid; Urastoma cyprinae (Graff, 1913), a gill turbellarian; Proctoeces maculatus (Looss, 1901), a trematode, and Mytilicola intestinalis (Steur, 1902), an intestinal copepod.

Table 1. Mytilus galloprovincialis infested with Eugymnanthea inquilina. Percentage of infested mussels and abundance of hydroid during sampling period at 3 stations in Thermaikos Gulf (north Aegean Sea) as a function of mussel length (ML) and position on culture ropes (top and bottom). Hydroid abundance divided into 3 classes: I $=1-50$, II $=51-100$ and III $=>100$ polyps. N: number of mussels infested with hydroids; NT: number of infested mussels. NT, NB: number of infested mussels on top and bottom of culture ropes, respectively

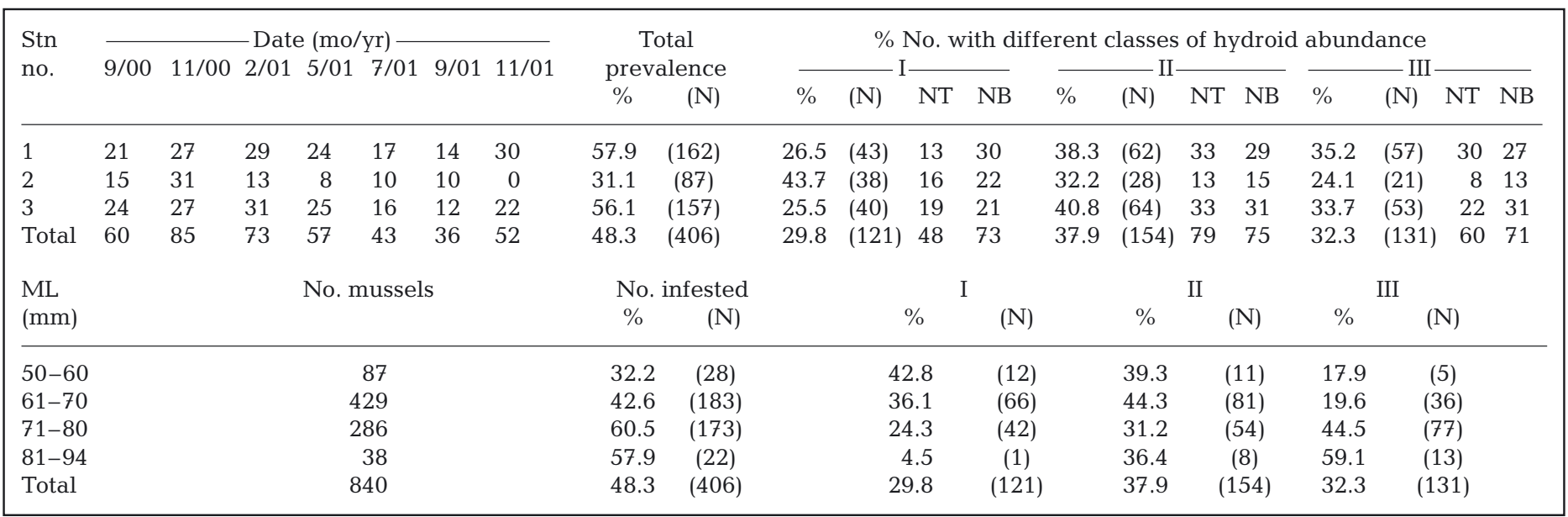




\section{Occurrence of Eugymnanthea inquilina}

Of the 840 mussels examined, 406 (48.3\%) were harbouring the hydroid Eugymnanthea inquilina (Table 1). Prevalence and hydroid abundance was significantly lower at Stns 2 than at Stns 1 and $3\left(\chi^{2}=10.6, p=\right.$ 0.0315). During the hottest months (May to September), the percentage of mussels infested by hydroids was at its minimum at all 3 stations (Fig. 2). The coefficient of variation was lower at Stns 1 and 3 (0.105 and 0.107, respectively) than at $\operatorname{Stn} 2(0.282)$. The branched hydroid forms were common throughout the year, but asexual budding of polyps sharply decreased in February, and formation of a medusa bud occurred in every host associated with polyps in July, with $50 \%$ of polyps in September 2000 and 2001, and a sharp decrease in November. No medusa bud formation occurred in February or May. High hydroid abundance (Class III) increased with increasing mussel length, whereas low hydroid abundance (Class I) decreased with increasing size $\left(\chi^{2}=38.3, p<0.001\right)$ (Fig. 3).

No significant difference $\left(\chi^{2}=3.69, \mathrm{p}=0.1577\right)$ was found in the abundance of hydroids between mussels from the top or bottom of the ropes. The mean CI of infested and non-infested mussels differed significantly (ANOVA; $F=66.26, \mathrm{p}<0.001$ ). Non-infested mussels had the highest CI (Fig. 4). Among infested mussels, those with high hydroid abundance (Class III) had the lowest CI (Fig. 4).

\section{Occurrence of Urastoma cyprinae}

Of the 840 mussels examined, 278 (33.1\%) were infested with Urastoma cyprinae, with a mean of 3 worms infested mussel ${ }^{-1}$ (Table 2). The prevalence and intensity of $U$. cyprinae differed between stations $\left(\chi^{2}=\right.$ 16.03, p < 0.0003). Highest prevalence and intensity
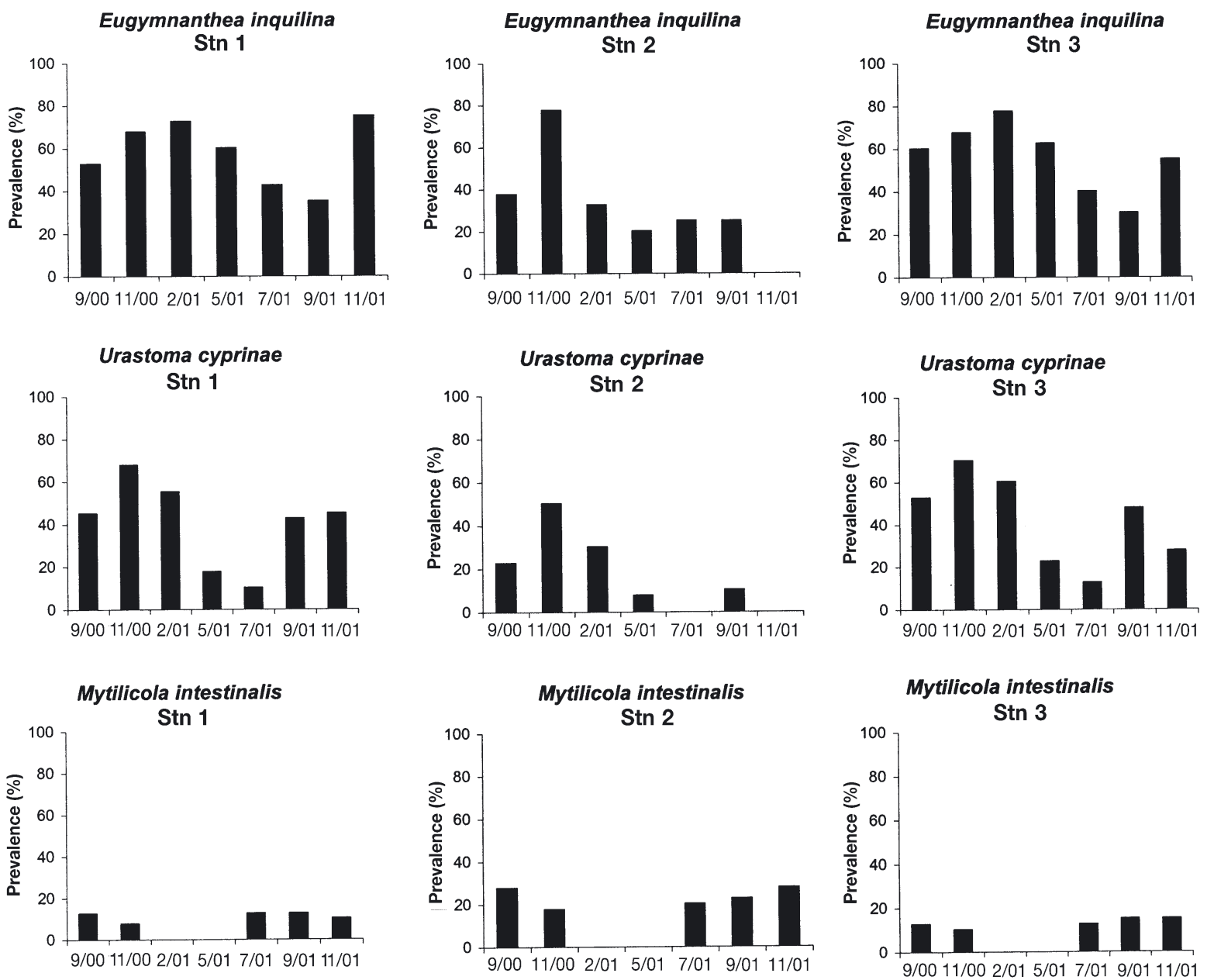

Fig. 2. Mytilus galloprovincialis. Monthly prevalence of 3 common metazoan parasites at sampling stations. Abscissas show mo/yr (e.g. 9/00 = September 2000) 
was at Stn 3, where 117 (41.7\%) mussels were infested, with a mean intensity of 3.7 worms infested mussel ${ }^{-1}$, while the lowest prevalence and intensity was recorded at Stn 2 (Table 2), with a mean of 1.6 worms infested mussel ${ }^{-1}$.

Prevalence and intensity of turbellarians were higher during the cold months (November 2000 to February 2001; temperatures 12 to $16.2^{\circ} \mathrm{C}$ ), while the lowest prevalence was recorded in July (Table 2, Fig. 2). The monthly prevalence of Urastoma cyprinae had a low cv at Stns 1 and 3 (0.201 and 0.204, respectively). In contrast, the cv was higher at Stn $2(0.428)$ as the parasite was absent from this station in July and November 2001. Infested mussels from the bottom of the ropes had a higher parasite prevalence and intensity than infested mussels from the top of the ropes $\left(\chi^{2}=3.10, p<0.10\right)$. In addition, larger mussels were more intensely infested $\left(\chi^{2}=9.81, \mathrm{p}=0.0203\right)$, with mussels 71 to $80 \mathrm{~mm}$ length showing maximum infestation (Fig. 3).

\section{Occurrence of Proctoeces maculatus}

The prevalence of Proctoeces maculatus was very low at all stations. Only 7 of the 840 mussels were infested by this parasite. The intensity of infestation by sporocysts was very high at Stn 1; 1 mussel contained thousands of sporocysts producing cercaria ready for emission from the sporocysts. Because of the low prevalence of this trematode, no statistical analysis was undertaken.

\section{Occurrence of Mytilicola intestinalis}

Generally, the infestation level and intensity of Mytilicola intestinalis was low. At the 3 stations, only
$94(11.2 \%)$ mussels were infested with $M$. intestinalis with a mean intensity of 1.1 copepods infested mussel $^{-1}$ (Table 3). Prevalence and intensity were significantly $\left(\chi^{2}=11.29, \mathrm{p}=0.0025\right)$ higher at Stn 2 , where $16.4 \%$ of the examined mussels were infested (some of them harbouring 4 copepods). The cv for the monthly prevalence of $M$. intestinalis was similar at all 3 stations $(0.287,0.287$ and 0.283 for Stns 1, 2 and 3, respectively). $M$. intestinalis was not found during February or May 2001 at the 3 stations (Fig. 2). The total male:female ratio of the copepods collected was 6.4:3.6, and most females had egg-sacs. Bottom-rope mussels were more highly infested, with some bearing 4 copepods, while top-rope mussels had no more than 1 copepod $\left(\chi^{2}=15.28, p<0.01\right)$. Infestation level increased with increasing mussel size $\left(\chi^{2}=9.81, \mathrm{p}<\right.$ 0.05, Fig. 3).

\section{Mussel CI and parasite level}

The mean CI of infested and non-infested mussels differed significantly (Fig. 4). In addition, the mean CI was dependent on the level of parasitism (ANOVA; $F=38.87, \mathrm{p}<0.01$ ). No significant differences were observed in the mean CI between mussels infested by 2 parasites (i.e. Eugymnanthea inquilina [Class III] + Mytilicola intestinalis or $E$. inquilina [Class III] + Urastoma cyprinae or $M$. intestinalis $+U$. cyprinae) and those infested by 3 parasites (LSD test: $\mathrm{p}>0.05$ ) (Fig. 4). These results indicate that the effects of different parasites on mussels are not equal, i.e. the CI is affected more by certain combinations of infestations (especially double and triple infestations with the combination of $E$. inquilina [Class III], U. cyprinae and M. intestinalis, Fig. 4).
Eugymnanthea inquilina

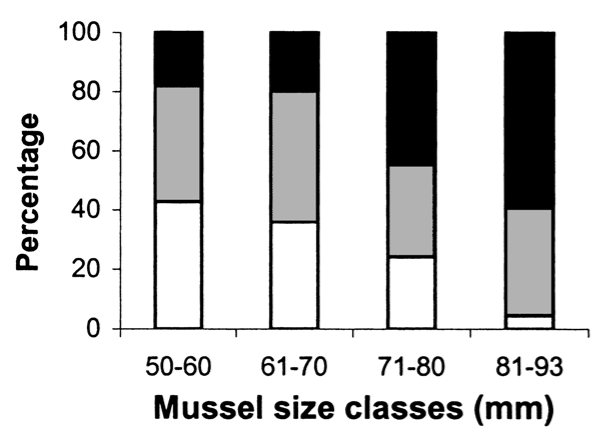

Urastoma cyprinae

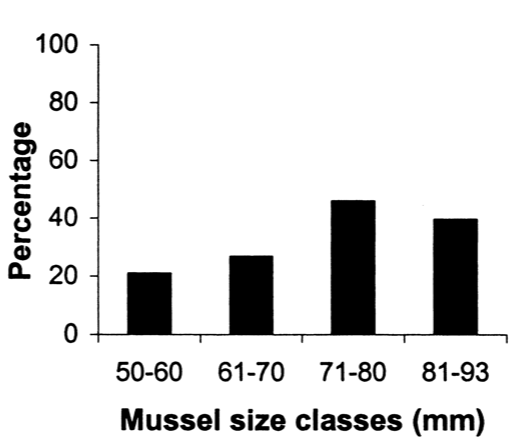

Mytilicola intestinalis

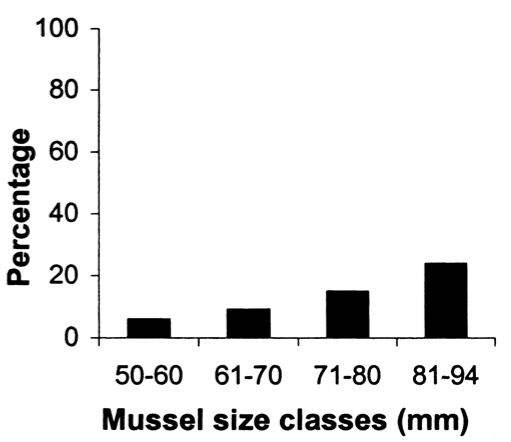

Fig. 3. Mytilus galloprovincialis. Percentage of infestation by 3 metazoan parasites as a function of mussel size. For Eugymnanthea inquilina, white, grey and black shading indicates low (Class I), medium (Class II) and high (Class III) hydroid abundance, respectively 


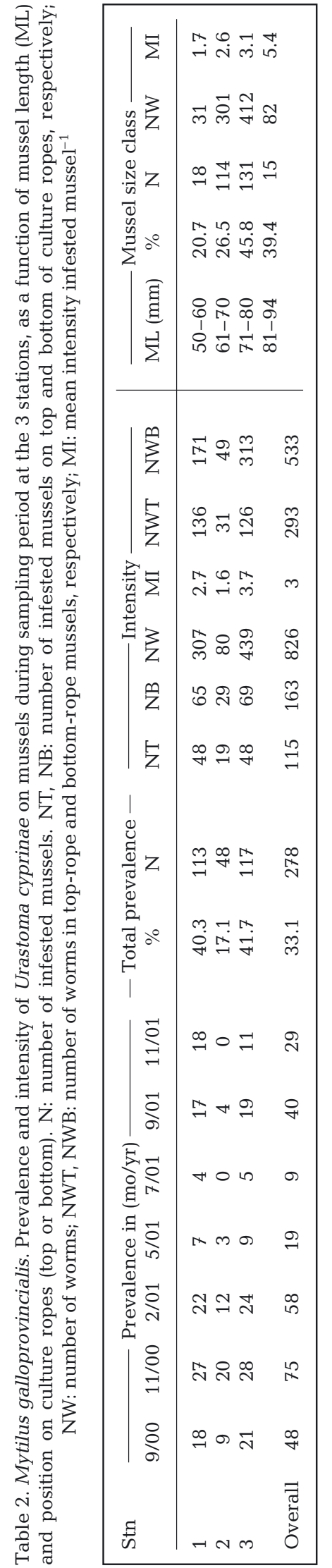

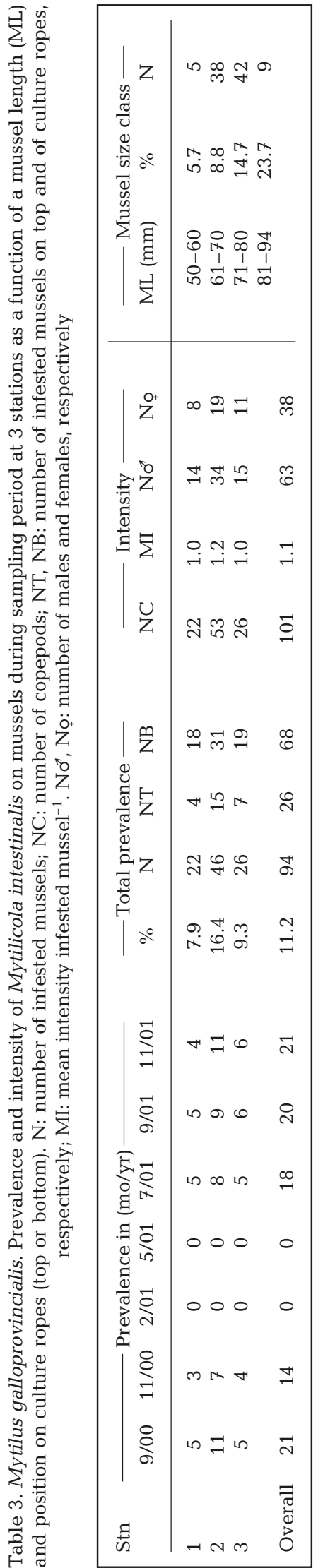

\section{DISCUSSION}

Little is known about parasites and the diseases of mussels compared to other cultured bivalves such as oysters (Bower 1992). Research at Aristotle University of Thessaloniki on parasitic organisms associated with cultivated mussels in the Thermaikos Gulf began 3 yr ago, and was integrated within a larger programme aimed at assessing the condition of the natural stock and cultivated populations of Mytilus galloprovincialis.

Except for Eugymnanthea inquilina, which has only been reported from Italian (Cerruti 1941, Kubota 1989, Piraino et al. 1994) and Greek (Rayyan et al. 2002), waters, the other 3 metazoan parasites have been recorded from a broad geographical range (NE Atlantic coast, North Sea, Mexican waters, South African waters, western Mediterranean and Black Seas: Dethlefsen 1974, Machkevski 1985, Cáceres-Martinez et al. 1996, Villalba et al. 1997, Calvo-Ugarteburu \& McQuaid 1998).

The prevalence of Eugymnanthea inquilina reported in this study ( 31.1 to $57.9 \%$ ) is higher than that reported for the Gulf of Naples, but lower than that reported for other areas (Table 4). In the present study, Stn 2 was characterised by a lower prevalence than the other 2 stations. The abundance of polyps was related to mussel size (i.e. large mussels had more polyps), which is in agreement with the results of Crowell (1957), Kubota (1983) and Piraino et al. (1994).

The reproduction of this polyp in the Thermaikos Gulf is similar to that reported by Piraino et al. (1994), in that the asexual budding of a daughter polyp of Eugymnanthea inquilina occurred throughout the year, although it decreased during the cold months. The formation of medusa buds occurred mostly during the warm season and very rarely in the cold months.

With regard to the host-hydroid interaction, although Cerruti (1941) supposed a ciliary loss from the mantle cells of inhabited mussels, Mattox \& Crowell (1951) and Kubota (1983) referred to hydroids living within bivalves as typical commensal organisms. Rees (1967) and Piraino et al. (1994) proposed that mutualism may occur, with the hydroid receiving some food and a sheltered environment in return for protecting the bivalve against other intruders. Despite previous suggestions of a commensal interaction between hydroids and mussels, in this study the hydroidinfested mussels, especially those with high hydroid abundance (Class III) displayed a signifi- 
Table 4. Mytilus galloprovincialis. Prevalence of the 3 parasites in different areas of the world

\begin{tabular}{|c|c|c|c|}
\hline $\begin{array}{l}\text { Parasite } \\
\text { Country }\end{array}$ & Location & Prevalence (\%) & Source \\
\hline \multicolumn{4}{|c|}{ Eugymnynthea inquilina } \\
\hline \multirow[t]{3}{*}{ Italy } & Gulf of Naples & 8 & Crowell (1957) \\
\hline & Pozzuoli, Taranto, La Spezia & $61.9-86.2$ & Kubota (1989) \\
\hline & Coastal sound of Taranto & 73.9 & Piraino et al. (1994) \\
\hline \multicolumn{4}{|c|}{ Urastoma cyprinae } \\
\hline Russia & Black Sea & 70 & Murina \& Solonchenko (1991) \\
\hline Spain & Galician Rias, NW Spain & $\approx 100$ & Villalba et al. (1997) \\
\hline Mexico & Baja California, NW Mexico & $56-100$ & Cáceres-Martinez et al. (1996) \\
\hline \multicolumn{4}{|c|}{ Mytilicola intestinalis } \\
\hline England & SW coast & 100 & Davey \& Gee (1976) \\
\hline Germany & North Sea & 100 & Dethlefsen (1974) \\
\hline
\end{tabular}

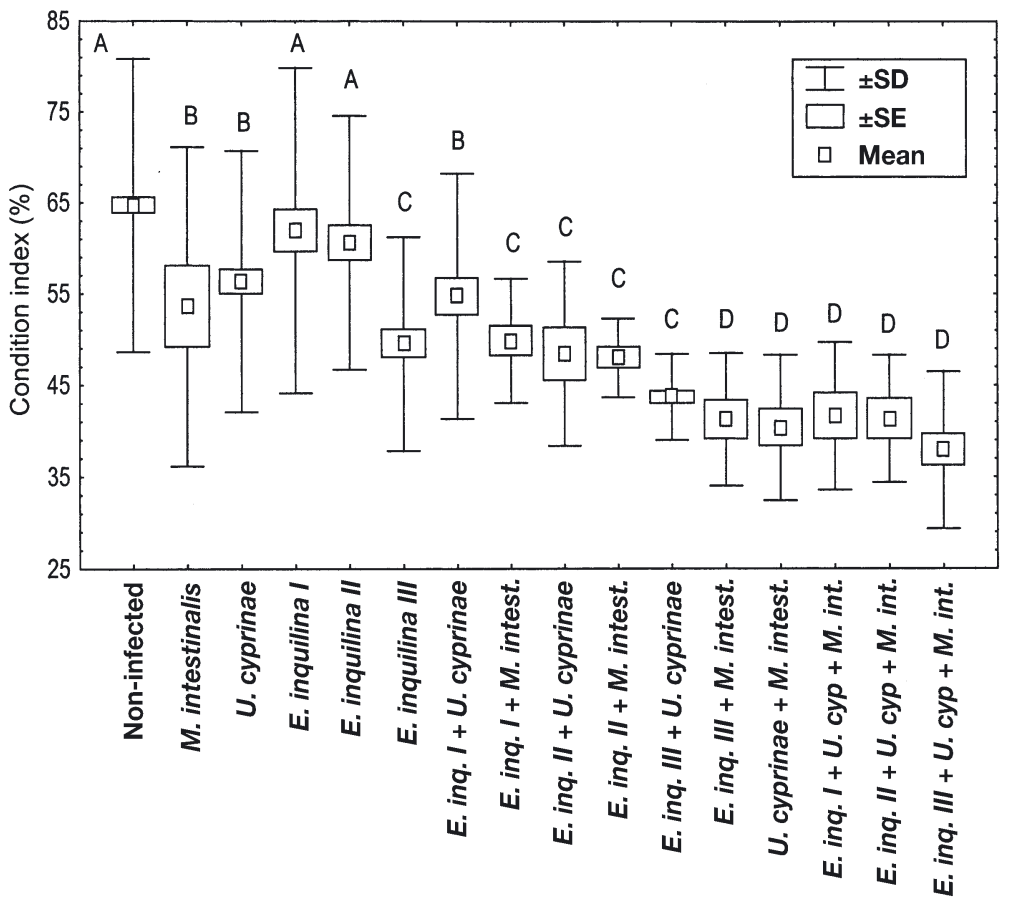

Fig. 4. Mytilius galloprovincialis. Box-whisker plots of CI and level of parasitism. Data bearing same letters do not differ from each other significantly (Fisher's LSD, p < 0.05). Full parasite names in Fig. 3

cantly lower CI than mussels with no hydroids. In addition, during dissection, in contrast to mussels with no hydroids, the meat of mussels with large numbers of hydroids was very watery and soft, and had an unpleasant smell.

With regard to factors affecting the prevalence and intensity of infestation of Mytilus galloprovincialis by Urastoma cyprinae, our study confirmed the results of Murina \& Solonchenko (1991) for the same host from the Black Sea, in that prevalence and intensity were higher in larger hosts and in mussels from the bottom portions of the ropes. Furthermore, U. cyprinae intensity was higher in winter. Murina \& Solonchenko (1991) suggested that the rate of infestation shows a seasonal pattern directly related to water temperature, with lower temperature resulting in a higher prevalence as well as an increased number of worms mus$\mathrm{sel}^{-1}$. The prevalence (17.1 to $41.7 \%$ ) recorded in this study was still lower than that reported from the Black Sea or Spanish and Mexican waters (Table 4). The significantly lower prevalence and intensity of $U$. cyprinae from mussels at the polluted station (Stn 2) agrees with the results of Cáceres-Martinez et al. $(1996,1998)$. The presence of flatworms can greatly reduce feeding capacity in heavily infested mussels (Robledo et al. 1994). Our study also revealed that mussels infested by $U$. cyprinae had a lower CI when compared to non-infested ones.

Proctoeces maculatus has not been detected in Mytilus galloprovincialis in South African waters (Calvo-Ugarteburu \& McQuaid 1998), and Villalba et al. (1997) recorded low prevalence of this parasite in mussels from Rias of Galicia (NW Spain). Results obtained from our study thus further confirm the low prevalence of $P$. maculatus in $M$. galloprovincialis.

In this study, prevalence and intensity of Mytilicola intestinalis in cultured Mytilus galloprovincialis was very low compared to reports from the English south coast and the German North Sea coast (Table 4). Describing monthly fluctuations in the infestation of $M$. intestinalis, Davey et al. (1978) reported that females of M. intestinalis breed twice, and that 2 generations of parasites coexist for most of the year, with recruitment taking place in summer and autumn. Dethlefsen (1974) recorded that the percentage of mussels infested by $M$. intestinalis is high in summer and low in winter, in 
agreement with our results. In the present study, male M. intestinalis were numerically dominant, and females with egg-sacs were present throughout the year, confirming the results of Hockley (1951) and Dethlefsen (1974). Our study also indicated that larger mussels were more often infested than smaller ones and that bottom-rope mussels were more infested than those near the surface. These findings agree with those of Hockley (1951), Hrs-Brenko (1967) and Davey \& Gee (1976), who suggested that the negative phototropism displayed by $M$. intestinalis larvae is responsible for their strong invasion of mussels from the bottom part of the rope and the weaker invasion of mussels attached to buoys, and that larger hosts attract more parasites than smaller individuals because of the higher filtration rate of the former. The significantly higher prevalence of $M$. intestinalis in the polluted Stns 2 in the present study agrees with data from Caspers (1939), who suggested that this parasite might be indicative of polluted water. In the present study, mussels infested with $M$. intestinalis had a significantly lower CI than noninfested mussels, confirming results of earlier studies (Durfort et al. 1982, Theisen 1987, Tiews 1988).

Acknowledgements. We wish to express our gratitude to Professor K. I. Stergiou for his kind assistance in improving the manuscript.

\section{LITERATURE CITED}

Aguirre MJ (1979) Biolgía del mejillón (Mytilus edulis) de cultivo de la Ria Vigo. Bol Inst Esp Oceanogr 5:107-160

Balopoulos E, Friligos NC (1993) Water circulation and eutrophication in the Northwestern Aegean Sea: Thermaikos Gulf. J Environ Sci Health A28:1311-1329

Bower SM (1992) Diseases and parasites of mussels. In: Gosling E (ed) Developments in aquaculture and fisheries science, Vol 25. The mussel Mytilus: ecology, physiology, genetics and culture. Elsevier, Amsterdam, p 543-563

Cáceres-Martinez J, Vásquez-Yeomans R, Sluys R (1996) Urastoma cyprinae in natural and cultured mussel (Mytilus galloprovincialis LMK) populations in Mexico. Bull Eur Assoc Fish Pathol 16:200-202

Cáceres-Martinez J, Vásquez-Yeomans R, Sluys R (1998) The turbellarian Urastoma cyprinae from edible mussels Mytilus galloprovincialis and Mytilus californianus in Baja California, NW Mexico. J Invertebr Pathol 72:214-219

Calvo-Ugarteburu G, McQuaid CD (1998) Parasitism and invasive species: effects of digenetic trematodes on mussels. Mar Ecol Prog Ser 169:149-163

Caspers H (1939) Über Vorkommen und Metamorphose von Mytilicola intestinalis Steuer (Copepoda paras.) in der südlichen Nordsee. Zool Anz 126:161-171

Cerruti A (1941) Mytilhydra polimantii n. gen., n. sp., idroide vivente sul mantello dei mitili. Riv Biol 32:1-18

Chintiroglou CC, Arsenoudi P, Scouras Z (2002) Identification of natural populations of the edible bivalve Mytilus galloprovincialis LMK and the study on the population structure in the Gulf of Thessaloniki and Thermaikos (N. Aegean). In: Ninth International Congress on the Zoogeography and
Ecology of Greece and Adjacent Regions (ICZEGAR). Hellenic Zoological Society, Thessaloniki, p 10

Crowell S (1957) Eugymnanthea, a commensal hydroid living in pelecypods. Pubbl Staz Zoo Napoli 30:162-167

Davey JT, Gee JM (1976) The occurrence of Mytilicola intestinalis Steuer, an intestinal copepod parasite of Mytilus, in the south-west of England. J Mar Biol Assoc UK 56:85-94

Davey JT, Gee JM, Moore SL (1978) Population dynamics of Mytilicola intestinalis in Mytilus edulis in South West England. Mar Biol 45:319-327

Dethlefsen V (1974) Seasonal fluctuations in two parasitic copepods Mytilicola intestinalis Steuer and Modiolicola insignis Aurivillius. Ber Dt Wiss Komm Meeresforsch 23:376-392

Durfort M, Bargalló B, Bozzo MG, Fontarnau R, López-Camps J (1982) Alterations des ovocytes de Mytilus edulis L. (Mollusca: Bivalvia) dues a l'infestation de la moule par Mytilicola intestinalis, Steuer (Crustacea, Copepoda). Malacologia 22:55-59

Hockley AR (1951) On the biology of Mytilicola intestinalis Steuer. J Mar Biol Assoc UK 30: 223-232

Hrs-Brenko M (1967) Mytilicola intestinalis Steuer (Copepoda parasitica), a parasite in mussels in the East Adriatic. Thalassia Jugosl 3:143-156

Krestenitis NY, Valioulis IA (1997) Annual and seasonal variability of the baroclinic circulation of the Aegean Sea. Proc 5th Hell Symp Oceanogr Fish, I, Kavala, p 343-346

Kubota S (1983) Studies on life history and systematic of the Japanese commensal hydroids living in bivalves, with some reference to their evolution. J Fac Sci Hokkaido Univ Ser VI Zool 23:296-402

Kubota S (1989) Systematic study of a paedomorphic dervative hydrozoan Eugymnanthea (Thecata-leptomedusae). Zool Sci 6:147-154

Le Breton S, Chintiroglou CC (1998) Etude préliminaire de la structure de trois populations de moules Mytilus galloprovincialis LMK sur la côte est de la baie de Thessaloniki. Rapp Comm Int Mer Médit 35:558-559

Machkevski VK (1985) Some aspects of the biology of the trematode, Proctoeces maculatus, in connection with the development of mussel farms in the Black Sea. In: Hargis JW (ed) Parasitology and pathology of marine organisms of the world ocean. US Department of Commerce, Washington, DC, p 109-110

Mattox NT, Crowell S (1951) A new commensal hydroid of the mantle cavity of an oyster. Biol Bull (Woods Hole) 101: $162-170$

Murina GV, Solonchenko AI (1991) Commensals of Mytilus galloprovincialis in the Black Sea: Urastoma cyprinae (Turbellaria) and Polydora ciliata (Polychaeta). Hydrobiologia 227:385-387

Nikolaides G, Moustaka M (1990) The structure and dynamics of phytoplankton assemblage from the inner part of the Thermaikos Gulf, Greece. I. Phytoplankton composition and biomass from May 1988 to April 1989. Helgol Meeresunters 44:487-501

Palombi A (1935) Eugymnanthea inquilina nuova leptomedusa derivante da un atecato idroide ospite interno di Tapes decussates L . PSZN I: Mar Ecol 15:159-168

Piraino S, Todaro C, Geraci S, Boero F (1994) Ecology of the bivalve-inhabiting hydroid Eugymnanthea inquilina in the coastal sounds of Taranto (Ionian Sea, SE Italy). Mar Biol 118:695-703

Rayyan A, Christidis J, Chintitoglou CC (2002) First record of the bivalve-inhabiting hydroid Eugymnanthea inquilina in the eastern Mediterranean Sea (Gulf of Thessaloniki, north Aegean Sea, Greece). J Mar Biol Assoc UK 82:851-853 
Rees WJ (1967) A brief survey of the symbiotic associations of Cnidaria with Mollusca. Proc Malacol Soc Lond $37: 213-231$

Robledo JAF, Cáceres-Martínez J, Sluys R, Figueras A (1994) The parasitic turbellarian Urastoma cyprinae (Platyhelminthes : Urastomidae) from blue mussel Mytilus galloprovincialis in Spain: occurrence and pathology. Dis Aquat Org 18:203-210

Editorial responsibility: Albert Sparks, Seattle, Washington, USA
Theisen BF (1987) Mytilicola intestinalis Steuer and the condition of its host Mytilus edulis L. Ophelia 27:77-86

Tiews K (1988) Die Miesmuschel in der Ökologie des Wattenmeers. Inf Fischwirt 35:110-112

Villalba A, Susana GM, Maria JC, Carmen L (1997) Symbionts and diseases of farmed mussel Mytilus galloprovincialis throughout the culture process in the Rias of Galicia (NW Spain). Dis Aquat Org 31:127-139

Submitted: August 29, 2002; Accepted: July 4, 2003

Proofs received from author(s): September 17, 2003 